ORIGINAL ARTICLE

\title{
Historical change in the traditional use of forests and its association with belief in tiger spirits in the Cardamom Mountains, Cambodia: The impact of war and wildlife trade on the relationship between humans and tigers
}

\author{
Hiroyuki Ishibashi ${ }^{1 *}$, Makoto Inoue ${ }^{1}$ and Motomu Tanaka ${ }^{2}$ \\ ${ }^{1}$ Department of Global Agricultural Sciences, Graduate School of Agricultural and Life Sciences, The University of Tokyo 1-1-1 \\ Yayoi, Bunkyo-ku, Tokyo, 113-8657, Japan. \\ ${ }^{2}$ Decision Science Center for a Sustainable Society, Kyushu University, 6-10-1 Hakozaki, Higashi-ku, Fukuoka, 812-8581, \\ Japan. \\ *Corresponding author: h_m_ishibashi@yahoo.co.jp
}

\begin{abstract}
This article explores changes in the traditional use of forests and their relationship with belief in tiger spirits in the Cardamom Mountains in southwest Cambodia. Locals inhabiting the mountains believe that spirits associated with tigers bite those who violate taboos on forest use. However, the tiger population has declined due to the wildlife trade, which experienced rapid growth during the civil war of the 1990s. The article examines the impact of the war and wildlife trade on the traditional use of the forest by analyzing the relationships among traditional beliefs, changes in the tiger population caused by the growth of the wildlife trade, and war-related changes in the social order. Before the war, beliefs associating tigers with forest use could be observed on several societal levels. The belief that tigers punish violators was practiced on village and inter-village levels, while another form of belief was also practiced on family and individual levels. However, the tiger's disappearance from the region because of the wildlife trade made such beliefs ineffective. A new belief arose that violators were punished by crop damage caused by wild pigs and other animals. Nevertheless, those who practiced the belief at the individual and family levels still believed in the association between the tiger and spirits and their role in forest use. Therefore, the impact of the aforementioned factors on tiger beliefs differed according to societal level; the extinction of living tigers does not necessarily result in the disappearance of belief at all levels of society.
\end{abstract}

Key words: tiger, belief, traditional use of forests, historical change, Cambodia

\section{INTRODUCTION}

Role of taboos and supernatural beliefs in natural resource management

Studies on natural resource management and use have revealed that social taboos and supernatural beliefs embedded in the local socio-cultural context play a role in conserving nature (Colding and Folke 2001; Sasaoka 2012; Sasaoka and Laumonier 2012). Social taboos are "a subset of informal institutions" that "guide human conduct toward the natural environment" (Colding and Folke 2001). In some indigenous societies, supernatural agents are believed to be involved in enforcing and sanctioning violations of taboos (Sasaoka 2012; Sasaoka and Laumonier 2012). Sacred forests and groves also promote conservation by placing constraints on forest use through the endowment of metaphysical value (Hamilton 2002). However, the growing external demand for resources and improved access to regional centers is resulting in the deforestation of sacred groves and a weakening of taboos (Gadgil and Varatak 1976; Kent 2010). Recent studies acknowledging such globalized changes and their implications for local forest use tend to explore historical changes in these sites (Dove et al. 2011; Sheridan 2008). Such studies provide important information for exploring how natural resource use based on supernatural beliefs adapts to change and supports locals' self-directed resource management (Sasaoka 2012).

Relationship between traditional use of forests and tiger beliefs

The Cardamom Mountains in southwest Cambodia are inhabited by indigenous minority groups called the Somrai and the Chong, who belong to the Mon-Khmer Pearic group of the Austroasiatic family (Isara 2002) and who distinguish themselves from dominant ethnic Khmers. These groups' traditional use of the forest is associated with a belief in tiger spirits. According to stories told by the Chong and 
Somrai, belief in spirits dates back to the time when their ancestors first settled in the mountains. These beliefs are described by villagers as Brahmanism (promenh sasana), forest beliefs (chomnuea prei), and the religion of the hunter (sasana prean). The Khmer also believe in spirits, but the characteristics of these spirits may differ according to region. Like the Khmer, the Somrai and Chong refer to spirits as areak, neak ta or lok ta. In Khmer folk religion, the areak is a vicious spirit that dwells in the forest, though it can also be a tutelary ancestral spirit (Ang 1986). Areak possess and speak through spirit mediums during annual séances and may also appear in human or animal form (Ebihara 1968). Neak ta are guardian spirits that safeguard the thing or area that they inhabit (Ebihara 1968). Neak ta include spirits that dwell in trees, rice paddies, streams, mountains and those associated with a particular territory (Ebihara 1968). The distinction between araek and neak ta is vague, and both protect those who respect them and give them offerings. They are believed to bring illness or trouble if disrespected (Ebihara 1968). Spirits in the group's animistic practices demonstrate the same characteristics. In addition, among the Somrai and Chong, araek and neak ta include ancestor spirits of early settlers or tribal leaders (Anonyomous 1968; Baradat 1941) and tiger spirits.

In Somrai and Chong villages, tigers are feared and awed of as agents that bite and punish violators of taboos. This belief can be observed in the harvest ceremony of cardamom that was commonly practiced in the Cardamom Mountains until the 1960s (Anonymous 1968; Baradat 1941; Martin 1997), and in other local ceremonies for uses of the forest.

In Khmer, the tiger (Panthera tigris) is called "khla" or "khla thum" (Boonratana 1999: 18; Long et al. 2000). The term "khla" may indicate other related species or other animals when combined with another word (Table 1). Other animals whose names contain "khla", however, do not seem to be associated with specific spirits. The use of "khla" as a single term is usually used to indicate tiger. The Chong name for the tiger is the same that used by the Khmer. The Somrai also use the same term. However, in their language, the tiger is also known as "khchi", "rovai" and "suu". "Suu" indicates a "spirit tiger". Additionally, the term "khla krâhâm (literally red khla)" is used by the Chong and also seems to mean "tiger". Hereafter, "khla", when used alone, is translated as "tiger".

Overall, three types of tigers are found in Somrai and Chong villages. The first is the tiger that punishes violators of taboos on the traditional use of the forest. This type is commonly found in both Somrai and Chong villages. The second, the "spirit tiger", is summoned during a ceremony and possesses a medium. This belief has only been confirmed among the Somrai and has not been found among the Chong. The final type is a tiger that physically attacks a human and/or whose population in the mountains is countable, which is equivalent to the English term "tiger" (Panthera tigris).

\section{War and wildlife trade in the mountains}

In the latter half of the $20^{\text {th }}$ century, a series of events introduced drastic changes in the traditional use of the forest in the mountains (Table 2). During this period, Cambodia experienced unstable sociopolitical conditions due to political conflict among diverse forces (Amakawa 2001). After gaining independence from the French colonial government in 1953, political conflicts intensified and eventually resulted in a civil war in the early 1970s. This war ended when communist forces, known as the Khmer Rouge, gained control of the state and established Democratic Kampuchea (1975-79). This government implemented a policy that denied the existing society, abolished religious practice, forcefully relocated villagers, and purged those who were thought to oppose the regime. This regime ended when another force that had escaped the purge gained support from the Vietnam military, toppled the existing government, and established the People's Republic of Kampuchea. Khmer Rouge forces fled to the mountainous regions on the Cambodia-Thai border and engaged in combat with the Vietnam-sponsored government, creating another civil war. This conflict was quelled in the early 1990s when a peace agreement was signed and the United Nations Transitional Authority in Cambodia arrived to prepare for an election. However, the battle began again after the new government was established in 1993. The Khmer Rouge had refused to participate in the election and continued to wage war until the late 1990s, when a resisting force was integrated into the government. The Cardamom Mountains were a stronghold of the Khmer Rouge forces and were transformed into a battlefield during the war. In addition, when the war ended, the wildlife trade grew rapidly, endangering the tiger population in the mountains (Nowell et al. 1999; Weiler et al. 1999). It is in this context that the traditional uses of the forest associated with belief in tiger spirits have evolved.

\section{Studies on tiger beliefs}

Tiger beliefs in Southeast Asia, particularly in the Malay region, have been studied primarily from historical 
Table 1. Scientific name and local classification of the tiger and other related species with similar local name in the research area

\begin{tabular}{|c|c|c|c|c|}
\hline Family & Species & Common name & Khmer/Chong name & Somrai name \\
\hline \multirow[t]{4}{*}{ Felidae } & Panthera tigris & Tiger & Khla / Khla thum/ Khla krâhâm** & Khchi /Rovay/Suu* \\
\hline & Panthera pardus & Leopard & Khla rokhen & Lmung \\
\hline & Neofeils nebulosa & Clouded leopard & Khla popok & n.d. \\
\hline & $\begin{array}{l}\text { Prionailurus viverrinus } \\
\text { Viverra megaspila }\end{array}$ & $\begin{array}{l}\text { Fishing Cat } \\
\text { Large-spotted Civet }\end{array}$ & Khla trey*** & n.d. \\
\hline \multirow[t]{2}{*}{ Ursidae } & Ursus thibetanus & Asiatic Black Bear & Khla khmum thum & Khchi chang \\
\hline & Helarctos malayanus & Malay Sun Bear & Khla khmum tauch & \\
\hline
\end{tabular}

Source: Boonratana (1999: 18), Holden and Neang (2009), Long et al. (2000) Anonymous (1968: 16), The IUCN Red List of Threatened Species (http://www.iucnredlist.org/details/22824/0\#) (cited February 20, 2015) and fieldwork by the first author.

* "Suu" indicates 'spirit tiger' summoned during the ceremony which was only confirmed for the Somrai and not for the Chong.

** A term called "khla krâhâm (literally red khla)" is mentioned by the Chong. The Somrai also associate tiger with red color. A medium possessed by a spirit tiger every time wears red clothes.

*** Early record of the "Fishing Cat" or "khla trey" was confirmed from its tracks commonly found on roads in a dry deciduous forest at $250 \mathrm{~m}$ above sea level (Long et al. 2000: 58, 209). However, recent study say that local name "khla trey" is often used to indicate both the Fishing Cat (Prionailurus viverrinus) and the Large-spotted Civet (Viverra megaspila), which the latter was camera-trapped in the marshlands and fragment forests at $560 \mathrm{~m}$ above sea level (Holden and Neang 2009).

Table 2. Main historical events related to the war and wildlife trade in Cambodia and in the Cardamom Mountains in the 20th century

\begin{tabular}{|c|c|c|c|}
\hline $\begin{array}{l}\text { Cambodian gov- } \\
\text { ernment }\end{array}$ & Year & Events at national level & Events in the Cardamom Mountains \\
\hline $\begin{array}{l}\text { Kingdom of Cam- } \\
\text { bodia } \\
(1953-1970)\end{array}$ & 1953 & Independence form the French colonial government. & \\
\hline $\begin{array}{l}\text { Khmer Republic } \\
(1970-1975)\end{array}$ & $1970-75$ & $\begin{array}{l}\text { Civil war between the government and communist } \\
\text { forces known as the Khmer Rouge. }\end{array}$ & Khmer Rouge force controled over the mountains \\
\hline \multirow{2}{*}{$\begin{array}{l}\text { Democratic Kam- } \\
\text { puchea } \\
(1975-1979)\end{array}$} & $1975-79$ & $\begin{array}{l}\text { Khmer Rouge gained control of the state and estab- } \\
\text { lished the new government. They implemented a } \\
\text { policy that prohibited religious practice, forcefully } \\
\text { relocated people, and purged those who were thought } \\
\text { to oppose the regime. }\end{array}$ & \multirow[t]{2}{*}{$\begin{array}{l}\text { The Somrai and Chong were relocated from the } \\
\text { old villages. }\end{array}$} \\
\hline & $1978-79$ & $\begin{array}{l}\text { A group that had escaped the purge gained support } \\
\text { from the Vietnam military and toppled the existing } \\
\text { government. }\end{array}$ & \\
\hline $\begin{array}{l}\text { Peoples' Republic } \\
\text { of Kampuchea } \\
\text { (1979-1989) }\end{array}$ & 1979 & $\begin{array}{l}\text { - Establishment of new government by a group that } \\
\text { gained support from the Vietnam military. } \\
\text { Khmer Rouge forces fled to the Cambodia-Thai } \\
\text { border and formed resistance forces that led to civil } \\
\text { war with the Vietnam-sponsored government. }\end{array}$ & $\begin{array}{l}\text { - The mountains were a strong hold of Khmer } \\
\text { Rouge forces and were a battle field during the } \\
\text { war. } \\
\cdot \text { Refugee camps were organized at the Thai bor- } \\
\text { der. }\end{array}$ \\
\hline $\begin{array}{l}\text { State of Cambo- } \\
\text { dia (1989-1993) }\end{array}$ & 1989 & Withdraw of the Vietnam military from Cambodia. & $\begin{array}{l}\text { The Somrai fled to border refugee camps. } \\
\text { - The Chong fled to the forest. }\end{array}$ \\
\hline \multirow{3}{*}{$\begin{array}{l}\text { United Nations } \\
\text { Transitional Au- } \\
\text { thority } \\
(1991-1993)\end{array}$} & 1991 & Peace agreement was signed at Paris. & \multirow[b]{2}{*}{$\begin{array}{l}\text { - Growth of the wildlife trade. } \\
\text { - The Somrai started to settle in Village A. } \\
\text { - The Chong started to settle in Village B }\end{array}$} \\
\hline & 1993 & $\begin{array}{l}\text { National election. Khmer Rouge bycotted the elec- } \\
\text { tion. }\end{array}$ & \\
\hline & 1994-97 & Battle between Khmer Rouge and the government. & \\
\hline \multirow{2}{*}{$\begin{array}{l}\text { Kingdom of Cam- } \\
\text { bodia }\left(1993^{-}\right)\end{array}$} & 1998 & \multirow[b]{2}{*}{ Integration of resisiting force into the government. } & · Hunter survey was conducted. \\
\hline & 1999 & & $\begin{array}{l}\text { - Wildlife survey was conducted. } \\
\text { - Official ban on wildlife trade and hunting. }\end{array}$ \\
\hline
\end{tabular}

Source: Amakawa (2001), Boonratana (1999), Nowell et al. (1999), Martin (1997), Vickery (1999) and field work by the first author. 
and anthropological perspectives (Boomgaard 2002; Wessing 1986). Historians reported that declines in the tiger population were caused primarily by incentives provided by the colonial governments in the Malay region and Indochina (Boomgaard 2002; Guérin 2010). However, these studies do not discuss how tiger beliefs changed after the tiger population decreased. A historical study on the relationship between humans and tigers in China showed an interrelation among changes in the sociopolitical order, human impacts on the ecological system and cultural meanings assigned to the tiger (Ueda 1999; 2002).

Studies on the relationship between humans and tigers in Cambodia are, however, scarce. Those that do exist focus on foreigners' views of the tiger rather than on local beliefs. For example, a historical study based on archival sources focused on the ways in which the French view of the tiger changed as tiger populations declined in Indochina during the French colonial period in the mid- $19^{\text {th }}$ century (Guérin 2010). The analysis explains that, by the 1950s, tigers could only be found in remote forests and mountains because of intensified hunting. An ethnological study performed in the Cardamom Mountains in the mid- $20^{\text {th }}$ century mentions tigers but only provides a brief description (Anonymous 1968; Martin 1997). Thus, little is known about the relationship between locals and tigers in forested areas after the colonial period.

Moreover, research on historical and contemporary changes in the traditional use of the forest due to the abovementioned events and their relationship to tiger beliefs in Somrai and Chong villages is rare because the instability of the region made the area inaccessible until the last decade of the 20 th century. The few available studies focus on the impact of conservation activities and economic development on traditional resource management in indigenous societies in the northeast provinces (e.g., Bourdier 2009; Ironside 2013).

\section{Aim and objective}

This paper aims to fill the aforementioned research gap by providing qualitative data collected through intensive fieldwork in southwest Cambodia. The overall objective of the paper is to explore changes in the traditional use of the forest and the relationship between these changes and belief in tiger spirits. Specifically, the article investigates 1) the role of the tiger as a punishing agent in traditional forest use before the war as a common characteristic of tiger belief in both Somrai (Village A) and Chong (Village B)villages $;{ }^{1} 2$ ) the effect of external pressures, especially the civil war and the growth in the wildlife trade, on the effectiveness of the belief that tigers are punishing agents; and 3) whether and how the changes resulted in different forms of belief in the two villages. These aims are important for understanding not only the impact of the war on wildlife (Loucks et al. 2009) but also on the relationship between people and wildlife that has shaped humans' approach to nature in the mountains. It also has practical implications, providing insight into the conservation of endangered animals from a local perspective.

\section{METHODOLOGIES}

The relationship between humans and tigers is analyzed to identify changes in the traditional use of the forest and their relationship with beliefs in a tiger spirit. "Tradition" here is defined as "a set of norms and taboos practiced by humans to make a living using nature while surviving threats from nature and the outside world by communicating with nature and spirits". This definition is tailored to the local context and is based on the empirical cases mentioned below. However, the definition is provisional and does not imply that tradition is static. Rather, the intent is to understand how it changes or is maintained over time as external conditions change. The traditions analyzed include the use of cardamom and other traditional uses of the forest associated with tigers. Changes in the relationship between humans and tigers are analyzed by focusing on the relationships among different forms of tiger belief, the growth of the wildlife trade and associated changes in the tiger population, and war-related changes in the social order.

\section{Study site}

\section{The Cardamom Mountain Region}

The Cardamom Mountains are located in southwest Cambodia along the Cambodia-Thai border (Fig. 1). As the name indicates, it is a prominent site for producing cardamom (Amomum kravanh), locally called krâvanh (Fig. 2), as it is referred to hereafter.

This region is settled by members of the Pearic language group, whose range extends from the eastern provinces of Thailand to the western provinces of Cambodia (Isara 2002). This article focuses on two members of this group, the ethnic Chong and Por/Somrai ${ }^{2}$. The Chong live amid the mountains in the Pursat and Koh Kong provinces; 


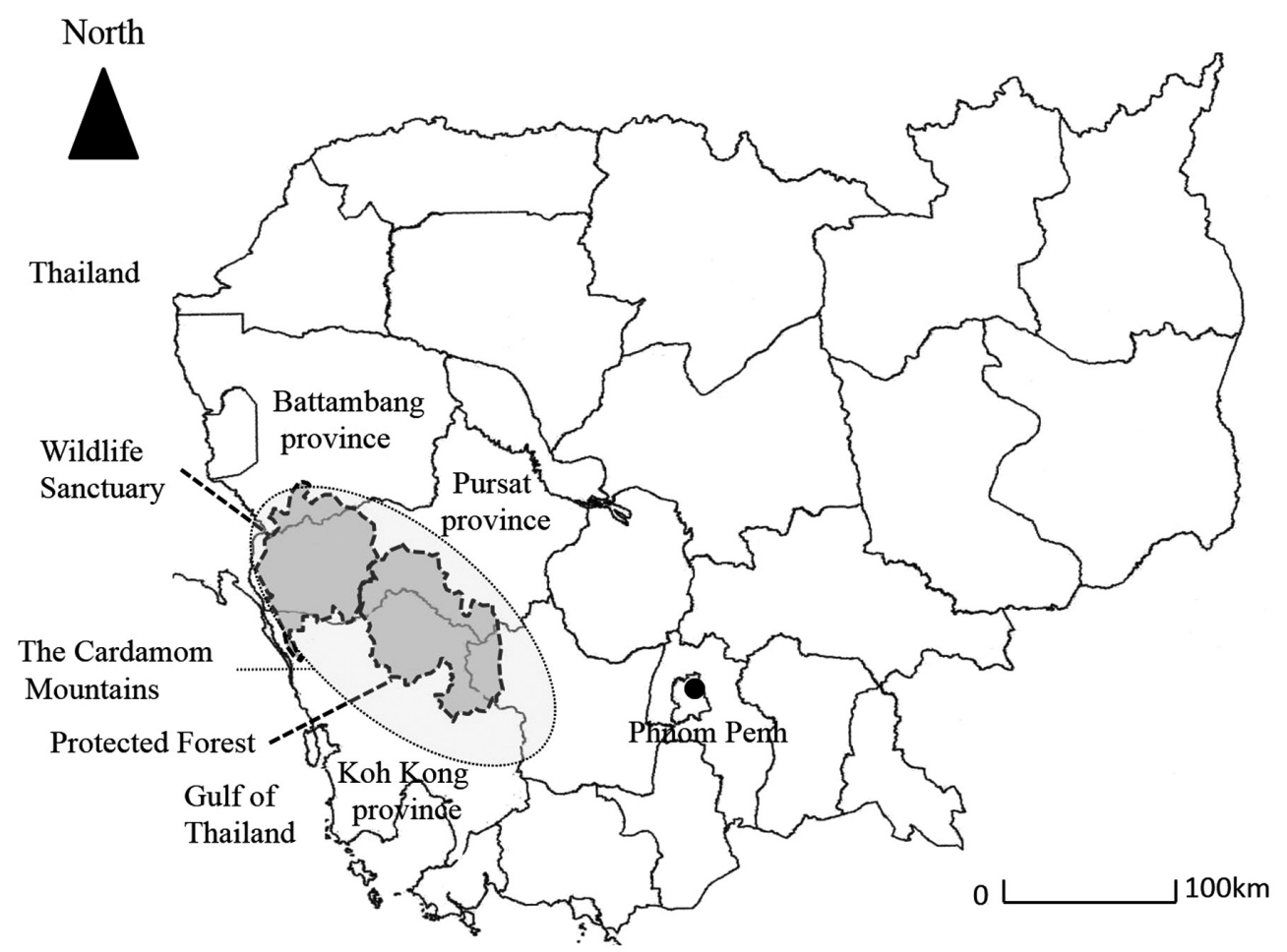

Fig. 1. Study Area in the Cardamom Mountains, Cambodia. Solid lines show the boundary of provinces. The circle with dotted line shows the approximate location of the Cardamom Mountains. The gray figures with dotted line shows the location of the wildlife sanctuary and the protected forest where the research is conducted.

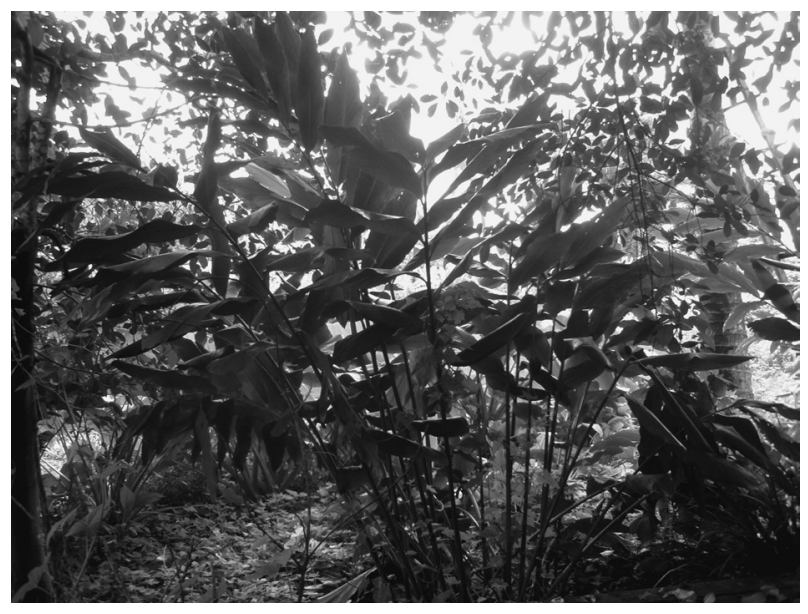

Fig. 2. Krâvanh plant

the Somrai live in the foothills of the mountains in Battambang province.

Until the 1960s, these groups' livelihoods consisted of cultivating paddy fields and other crops; collecting and trading forest products such as krâvanh, resin, and agar wood (Aquillaria crassna); and hunting. Traditions related to these activities, however, have changed, primarily because of events that occurred during the communist regime, the civil war and the growth of the wildlife trade.

After the war, a wildlife survey that was conducted in the Cardamom Mountains led to the initiation of protected forest management that included an area of 401,313 ha administered by the Forestry Administration and a wildlife sanctuary covering 332,655 ha administered by the Ministry of the Environment (Momberg and Weiler 1999; Fox 2007) (Fig. 1). The managed areas overlap with the forests and lands surrounding the villages where the Chong and Somrai live.

The main research sites for this study were the mountain villages inhabited by the Somrai (Village A) and the Chong (Village B). Village A is in Battambang province. It is the only village where the Somrai live. In 2011, 130 of the 169 households $^{3}$ were Somrai (788 people). The village is located near the Thai border. Until the 1960s, the Somrai lived in villages near the river, approximately 4 to $9 \mathrm{~km}$ east of the current village, where they say their ancestors first settled. According to ethnographic research conducted in the late 1960s and early 1970s (Anonymous 1968: Martin 1997 ) and stories told by the current villagers, the ancestors of the Somrai were two hunters that came from the Angor region (today's Siem Riep province). They were sent by a king to hunt for elephants. During their stay, they discov- 
ered krâvanh and other fruits, which they sent to the king. After receiving the krâvanh, which can be used in traditional medicine, the king ordered the hunters and their relatives to settle near the forest and send a continuous supply of krâvanh. The hunters and their relatives built the first village close to the krâvanh forest, and the Somrai lived there until the 1960s, just before the war erupted.

Village B is located in Pursat province. In 2011, 249 of the 289 households (1160 people) ${ }^{4}$ were Chong. The village is located nearby a krâvanh forest. Until the 1960s, most of the inhabitants of Village B lived in villages in a river valley and marshland surrounding the krâvanh forest, approximately 5 to $15 \mathrm{~km}$ southeast and, in the upland, approximately $5 \mathrm{~km}$ west of the current village. Of these villages, the village along the river valley is said to be the oldest and to mark where the first ancestors settled. Although there are several versions of the Chong's ancestor story, a relatively common version told today is that their first ancestors escaped from Siam, where they were being held captive 5 . The current village was established in the early 1990s by an elder named TS who is now worshiped as a village guardian spirit (neak ta, lok ta). After his death in approximately 1993, people began to worship him as a spirit and the ceremony was continued by relatives (Ishibashi 2010).

\section{Data Collection}

Primary data were collected by the first author through participant observation and open-ended interviews in the Khmer and Somrai languages. Participant observation was undertaken by staying in the two study villages and in other villages in the mountains. While staying in the village, the author obtained a deeper understanding of peoples' views toward nature and spirits through daily conversation and by observing and participating in local ceremonies, community activities supported by NGOs and village meetings. Openended interviews were conducted with farmers, shop keepers, local authorities, natural resource management committee members, school teachers, ex-soldiers, relatives of priests, and NGO and government staff. Village A and its neighboring villages were visited 8 times for a total of 105 days. Village B was visited 10 times for a total of 176 days. Tables 3 and 4 provide the basic information of key interviewees in the two villages. The number of key interviewees was 9 in Village A and 13 in Village B. Each interviewee's pseudonym, which will be used to cite their remarks, is also explained in the tables. The secondary data collected includes relevant literature, wildlife surveys and socio- economic reports prepared by government entities and organizations working in the field of conservation.

The data collection was conducted during the following periods: August 2007 and March 2008; August and September 2009; January to February 2010; during a two-yearstay in Cambodia from June 2010 to March 2012; and January to March 2013. Village A and Village B are the primary study areas, but findings from surrounding villages will also be mentioned when necessary.

\section{RESULTS}

\section{Tiger attack narratives and the origin of tiger-related ceremonies}

In Village A, there are two versions of the oral history detailing the Somrai's early experiences with tiger attacks, the emergence of a ceremony for reducing tiger attacks and the association of tigers with spirits. The first version of the story was narrated by A3:

When the people first settled, they were all hunters. At that time, they suffered almost every day from tigers biting people to death. One day the settlers made a cage and put a woman named JT inside as a sacrifice to capture the tiger. When the tiger appeared, the woman prayed for forgiveness. The tiger said, "If you don't want to be bitten, an annual ceremony should be held four times per year, in the months of kattek (November), boh (December to January), meakh (February) and pisakh (May)".

The second version of the story was narrated by A2. This version of the story also relates that the earlier settlers suffered from tiger attacks. However, the origin of the ceremony is described differently than in the first version:

A tiger tried to attack a man named TSB but could not bite him. Then, TSB threatened the tiger and said that he would burn the tiger's house (or habitat). He also added that his descendants would hold an annual ceremony four times a year if it stopped biting people.

Although the two versions do not agree on whether the human or the tiger took the initiative in negotiating for the commencement of the ceremonies, both versions of the story indicate that four annual ceremonies should be held every year. These ceremonies are saen kâttek (November), during which the wooden pole that symbolizes the life of 
Table 3. Key interviewees for Village A

\begin{tabular}{|c|c|c|c|}
\hline Pseudonym & Birth Period & Sex & Basic information of interviewees \\
\hline A1 & $1940 \mathrm{~s}$ & Male & $\begin{array}{l}\text { - A priest responsible for conducting the annual ceremony practiced four times a year. } \\
\text { - His father was both a priest of previous generation and an owner of the krâvanh forest. The } \\
\text { krâvanh forest owned by his father was located nearby the village which is said to be built by } \\
\text { the first ancestors of the Somrai. }\end{array}$ \\
\hline $\mathrm{A} 2$ & $1960 \mathrm{~s}$ & Male & Son of A1. \\
\hline A3 & $1930 \mathrm{~s}$ & Male & Relative in law of a priest of the previous generation. \\
\hline A4 & $1970 \mathrm{~s}$ & Male & A villager. \\
\hline A5 & $1940 \mathrm{~s}$ & Male & A villager. \\
\hline A6 & $1940 \mathrm{~s}$ & Male & A villager. \\
\hline A7 & $1950 \mathrm{~s}$ & Female & Aunt of A2. \\
\hline A8 & $1980 \mathrm{~s}$ & Male & Nephew of A7. \\
\hline A9 & $1940 \mathrm{~s}$ & Male & Husband of A7. \\
\hline
\end{tabular}

Source: Interview and observation form field work by the first author.

* All interviewees are the Somrai and does not include the Khmer migrants.

Table 4. Key interviewees for Village B

\begin{tabular}{|c|c|c|c|}
\hline Pseudonym & Birth Period & Sex & Basic information of interviewees \\
\hline B1 & $1940 \mathrm{~s}$ & Female & A villager. \\
\hline B2 & $1970 \mathrm{~s}$ & Male & A villager. \\
\hline B3 & $1900 \mathrm{~s}$ & Female & A villager. \\
\hline B4 & $1950 \mathrm{~s}$ & Female & $\begin{array}{l}\text { A villager. She was born in a village of the Chong in Koh Kong province but moved to the } \\
\text { current village during the war. }\end{array}$ \\
\hline B5* & $1940 \mathrm{~s}$ & Male & A Samre elder. His father was an owner of the krâvanh forest. \\
\hline B6 & n.d.** & Male & Son of a survior that stayed in the forest during the war. \\
\hline B7 & $1940 \mathrm{~s}$ & Male & A Villager. He has an experience of working for conservation activity. \\
\hline B8 & $1920 \mathrm{~s}$ & Male & A priest who succeeded TS and inherited the responsibility of conducting local ceremonies. \\
\hline B9 & $1960 \mathrm{~s}$ & Male & $\begin{array}{l}\text { A Khmer migrant from different district who married with a woman whose parents is local to } \\
\text { Village B. }\end{array}$ \\
\hline B10 & $1970 \mathrm{~s}$ & Male & $\begin{array}{l}\text { A Khmer migrant from different province who married with a woman whose parents is local to } \\
\text { Village B. }\end{array}$ \\
\hline B11 & $1950 \mathrm{~s}$ & Male & Relative of TS. \\
\hline B12 & $1950 \mathrm{~s}$ & Male & Son in law of TS. \\
\hline B13 & $1960 \mathrm{~s}$ & Female & A villager. \\
\hline
\end{tabular}

Source: Interview and observation form field work by the first author.

*A village where B5 lives is located in different place in the same district where Village B is located but B5 and people in Village B have been in contact since before the war.

**B6's birth year is unconfirmed but probably was born in the 1980s or later since his elder brother was born in the later half of 1970s.

the priest is exchanged; saen kap chomkar (December to January), which welcomes the season of clearing the forest for cultivation; saen meakh (February), in which participants pray for good health; and saen dam srou (May), which celebrates the season for planting rice. The four ceremonies are conducted by a hereditary priest called a $t a$ khvay. Two of the four annual ceremonies (saen kap chomkar and saen dam srou) restrict villagers from clearing the forest before the season for cultivation and rice planting begins. The villagers believe that the tigers will bite violators to death or that misfortune will befall them. Ethnographic research from the 1930s also reported taboos on cultivation and rice planting before the ceremonies and the belief that tigers would punish the violators (Baradat 1941). The four annual ceremonies are held in the priest's village, but the taboos related to the ceremonies were observed in the other Somrai villages. This suggests that the ceremony was held at the village or inter-village level ${ }^{6}$.

The ancestors who survived the tiger attacks in the both narratives became spirits. A2 and A4 reported that JT, TSB and other ancestor spirits mentioned during the annual ceremony are said to be those whom the tiger could not 
bite. The story is also related to a taboo that prohibits the priest who conducts the ceremony from hunting tigers. This taboo, described by A1 and A2, only applies to the priest and those from the same family line of the priest. A5, who does not belong to a priest's family, said that he had hunted tigers before the war. This shows that taboos on killing tigers were practiced at individual and family levels.

Similarly, the Chong in Village B also tell how their ancestors suffered from tiger attacks, and the ancestor that survived the attack came to be worshipped as a spirit. B1 indicates that this reverence is a reward for overcoming the attack, remarking, "The ancestors were captives of Siam and came here for refuge, at first with seven people. Only one of them survived. Others were bitten by a tiger. The one who survived became a guardian spirit (lok ta)". In Village $\mathrm{B}$, however, this story is not associated with a taboo prohibiting tiger hunting.

Tiger attacks were a real and regular threat to people in the Chong villages. B2 and B3 remembered how close a tiger preying on water buffaloes came to their village. B4 said she did not dare let her children wander far from the house because tigers (khla krâhâm) came close to the houses at night to eat dogs, ducks and chickens.

Ethnographic research in the 1960s also reported the appearance of tigers near houses at night (Martin 1997). The study also reported that two persons working at a swidden farm field in a dense forest were said to have been devoured by a tiger.

\section{Traditional practices for harvesting forest products until the 1960s}

One of the ceremonies instituted to prevent tiger attacks is the ceremony that celebrates the beginning of the season for krâvanh harvest. The ceremony involves supplicating the spirits to protect villagers from tiger attacks when they enter the forest to collect forest products. In Somrai villages, this ceremony was initially conducted by a hereditary forest owner called a dângkhaw krâvanh (Anonymous 1968; Baradat 1941). To secure the villagers' safety, the dângkhaw prepares offerings to the ancestor spirits, asks for permission to enter the forest and prays for the harvesters to be protected from tiger attacks (Anonymous 1968). Harvesting krâvanh before this ceremony is performed is prohibited, and such activities are described as "stealing". This prohibition is observed in all of the Somrai villages, and villagers are not allowed to begin harvesting until the season is officially opened at the forest near the oldest village where the ancestors first settled. According to A2, one man was killed by a tiger because he had stolen krâvanh before the season began. It appears that the Somrai usually adhere to tradition. According to A6, no one dared to break the tradition because they were scared that a tiger would attack the violators. These findings suggest that beliefs about violators of the krâvanh ceremony being punished by tigers were held at the inter-village level.

Following the guidance of spirits was also required after entering the forest. When A1 was asked whether he encountered tigers during the krâvanh harvest, he replied,

I never saw a tiger during the krâvanh harvest because the spirits of the ancestors guided us by telling us, "Don't go that way! Animals are there, walk this way". Once there was a person who went deep into the forest alone, but one should let others know (including the spirits) in such a case. The person who went ahead alone was found to have been mauled by a tiger; only an arm was left.

Although prohibitions were not always followed, the abovementioned cases show that beliefs associating tigers with spirits that punish violators were partially effective during this period. It also shows the villagers' fear of tigers.

In Village A, tigers were believed to attack humans but also to protect krâvanh for human use. According to A1 and A2, when krâvanh is planted, a spirit tiger will emerge and take care of the planted krâvanh. The spirit tigers also seem to be associated with the krâvanh planted in private gardens locally called suon. There were at least three owners of private krâvanh gardens in the 1960 s, i.e., X, a dângkhaw and the father of A1; Y, the dângkhaw's younger brother; and Z, Al's father-in-law. Today, there are at least two persons who are confirmed patrons of spirit tigers. Both of them inherited the spirit tigers from Z: A2, whose mother is Z's eldest daughter, and A7, a younger daughter of $Z^{7}{ }^{7} \mathrm{Y}$ had no children. This shows that the spirit tigers are held by individuals and are inherited by their descendants ${ }^{8}$. The spirits are summoned during ceremonies held by the descendants, during which these spirits possess a medium? ${ }^{9}$.

Hence, the role played by the spirit tiger in the traditional use of the forest is different from other forms of tigers associated with spirits. The spirit tigers protect krâvanh planted for the family's use, but tigers that punish violators seem to protect the whole forest for village or inter-village use, as described above.

The Chong in Village B also instituted traditions to protect themselves from tiger attacks when collecting krâvanh. They held a ceremony to open the krâvanh season in the forest near the current village. The ceremony was 
held at the inter-village level, and people from nearby villages attended the ceremony. It was conducted by a forest owner, who in this area is called either a dângkhaw krâvanh or a me smon (Baradat 1941: Martin 1997). The forest owner was a Somre who lived in a different village; the Somre and the Chong held their ceremony and participated in the krâvanh harvest together ${ }^{10}$. During the ceremony, people supplicated the spirits for protection when entering the forest. B5, a son of a forest owner, said, "I saw tigers and elephants during the krâvanh harvest, but I was not afraid because the ceremony was already done and we had asked the spirits for protection". After the harvest, supplemental planting of krâvanh is undertaken inside the forest where the plant is sparse. However, the spirit tiger that emerges after a krâvanh planting was not reported near Village B.

\section{Interruption of local ceremonies during the commu- nist regime (1975-1979)}

The communist regime established after the war in the early 1970s prohibited religious activities, and ceremonies related to forest use were therefore interrupted during this period. In some cases, local ceremonies were allowed in the early years of the regime because the prohibition of religious activity was not immediately implemented across the country (Vickery 1999) ${ }^{11}$. However, these limited ceremonies also became prohibited in the later years of the regime. In addition to the abolishment of religious practice, those who lived in the mountains were forced to move from their villages to relocation sites, where they were forced into agriculture labor; many lost their lives ${ }^{12}$. This also prevented people from practicing local ceremonies.

In Village A, it is said that, after repeated relocation during the 1970s, 300 Somrai died from starvation and illness in the late 1970s. A2 interpreted this as a misfortune caused by the interruption of the annual ceremony, which should be practiced every year.

In Village B, B8 emphasized that many died during the communist regime after 1975, when they were moved from the old village, because religious practice was abolished at that time. Although people from both villages associated these deaths with the interruption of the ceremony, the implications of the interruption for the relationship between humans and tigers are uncertain.

\section{Traditions during war-time post-1979}

Supported by the Vietnam military, a group of people who escaped the purge by the communist regime toppled the existing government in 1979. This, however, led to another civil war that was fought in the mountains. The deposed Khmer Rouge forces fled to the Thai border and began an armed conflict with the newly established government.

Informants indicate that, during the war, a small-scale harvest of krâvanh was carried out by individuals in the forest near the Thai border and elsewhere. However, people in both villages said that no ceremony to open the harvest season was held during this period because the warfare made it impossible.

Meanwhile, after the fall of the communist regime that had prohibited religious activity, a general sense of awe toward nature began to be recovered.

The Somrai in Village A fled to border refugee camps, and some of them visited the forest to make a living. A1 would supplicate spirits to help him find forest products in the mountains ${ }^{13}$ near the current village during this period.

Some of the Chong in Village B fled to the forest to hide during the war. TS, who later established Village B, lead those that hid inside the forest. B6, the son of a survivor of this episode, said that locals could tell which forest was safe and which forest should be avoided by identifying the tracks of predatory animals.

\section{Tiger population declines in the $1990 \mathrm{~s}$}

Although a general sense of awe toward nature was reportedly maintained during the war, this changed during the transition period from war to peace in the 1990s, when tiger hunting and the wildlife trade in the mountains grew rapidly. Wildlife survey reports indicate that hunters and traders came from Pursat and Koh Kong provinces and from Thailand to hunt tigers, elephants, bears and guars (Momberg and Weiler 1999). The most common methods employed were guns, snares and anti-personnel mines (Boonratana 1999). The abundance of tigers may have attracted hunters to this region. A hunter survey conducted in 1998 reported that the tiger density in the Cardamom Mountain region $\left(11,846 \mathrm{~km}^{2}\right)$ was the highest among the 9 regions ${ }^{14}$ surveyed in Cambodia (Nowell et al. 1999). The estimated number of adult tigers in the mountains ranged from 162 to 217 out of a total of 535 to 712 , though the risk of overestimating the actual population and of data inaccuracy was greater than in other countries (Nowell et al. 1999). Other studies give lower estimates of 146 to 198 out of a total of 436 to 591 (Sun 2000). The survey also reports the mountains as the only locations in Cambodia with significant man-eating tiger problems (Weiler et al. 1999). 
Wildlife hunting and trade were officially banned in January 1999 (Boonratana 1999), but the tiger population continued to decrease. It has been estimated that, in the 1990s, 100 to 200 tigers were exported from Cambodia each year (Gray 2012). In 2004, the estimated tiger population in the mountains, based on records collected by biologists and community wildlife rangers using camera traps and field surveys, ranged from only 5 to 20 out of a total of 11 to 50 in Cambodia (FA 2011).

\section{Impact of tiger hunting on traditional practices}

No information about tiger hunting near Village A in the 1990s is available, although considering the growth of the wildlife trade mentioned above, it is possible that hunting occurred. Nevertheless, people did not explicitly mention such activities, though they voluntarily mentioned hunting animals besides tigers for subsistence purposes during the war. People in this village generally tend to refrain from speaking about violations against tradition because to do so is believed to bring misfortune. This may ex-

Table 5-1. Changes in practice and effectiveness of traditions related to tiger beliefs in Village A

\begin{tabular}{|c|c|c|c|c|c|c|}
\hline No. & Case of traditions & $\begin{array}{l}\text { Content of traditions } \\
\text { (taboos, stories, cere- } \\
\text { monies) }\end{array}$ & $\begin{array}{l}\text { Condition of practice } \\
\text { since the } 2000 \mathrm{~s}\end{array}$ & $\begin{array}{l}\text { Explained background } \\
\text { for changes in traditions }\end{array}$ & $\begin{array}{l}\text { Practiced level } \\
\text { in society } \\
\text { before the war }\end{array}$ & $\begin{array}{l}\text { Practiced level } \\
\text { in society } \\
\text { after the war }\end{array}$ \\
\hline 1 & $\begin{array}{l}\text { Annual Ceremony* 1: } \\
\text { Saen k âttek } \\
\text { (November) }\end{array}$ & $\begin{array}{l}\text { The wooden pole that } \\
\text { symbolizes the life of } \\
\text { the priest is exchanged. }\end{array}$ & $\begin{array}{l}\text { In practice, but num- } \\
\text { ber of participants are } \\
\text { declining. }\end{array}$ & $\begin{array}{l}\text { Threats to human life } \\
\text { eased after the war. }\end{array}$ & $\begin{array}{l}\text { Village or } \\
\text { Inter Village** }\end{array}$ & Village \\
\hline 2 & $\begin{array}{l}\text { Annual Ceremony 2: } \\
\text { Saen kap chomkar } \\
\text { (December to January) }\end{array}$ & $\begin{array}{l}\text { - Begins the season for } \\
\text { calearing and cultivat- } \\
\text { ing the forest. } \\
\text { - Clearing the forest } \\
\text { for cultivation before } \\
\text { the ceremony is not al- } \\
\text { lowed. } \\
\text { - Those who clear and } \\
\text { cultivate the forest } \\
\text { before the season are } \\
\text { believed to be bitten by } \\
\text { a tiger. }\end{array}$ & $\begin{array}{l}\text { In practice, but some } \\
\text { villagers and migrants } \\
\text { started to clear the } \\
\text { forest for cultivation } \\
\text { before the ceremony. }\end{array}$ & $\begin{array}{l}\text { Crop damage by ani- } \\
\text { mals is interpreted by } \\
\text { villagers as a punish- } \\
\text { ment against violating } \\
\text { the ceremony. }\end{array}$ & $\begin{array}{l}\text { Village or } \\
\text { Inter Village }\end{array}$ & Village \\
\hline 3 & $\begin{array}{l}\text { Annual Ceremony 3: } \\
\text { Saen meakh } \\
\text { (February) }\end{array}$ & $\begin{array}{l}\text { The ceremony is prac- } \\
\text { ticed to pray for good } \\
\text { health. Period of the } \\
\text { ceremony lasts for two } \\
\text { weeks. First day and } \\
\text { last day of the ceremo- } \\
\text { ny is held at the priest' } \\
\text { s house which start } \\
\text { at night and end after } \\
\text { sunrise. Other remain- } \\
\text { ing day among the two } \\
\text { weeks is held each } \\
\text { night at the houses of } \\
\text { each family who have } \\
\text { spirit inherited from } \\
\text { their ancestors ( see Ta- } \\
\text { ble } 5-2, \text { No. } 7 \text { ). }\end{array}$ & $\begin{array}{l}\text { In practice, but weak. } \\
\text { The ceremony held } \\
\text { at the priest's house } \\
\text { was interrupted during } \\
\text { midnight and was re- } \\
\text { started in morning. }\end{array}$ & $\begin{array}{l}\text { The ceremony is be- } \\
\text { coming less active } \\
\text { from the decrease of } \\
\text { elder, medium, music } \\
\text { player for calling spir- } \\
\text { its. The younger gen- } \\
\text { eration do not believe } \\
\text { in beliefs. }\end{array}$ & $\begin{array}{l}\text { Village or } \\
\text { Inter Village }\end{array}$ & Village \\
\hline 4 & $\begin{array}{l}\text { Annual Ceremony 4: } \\
\text { Saen dam srou } \\
\text { (May) }\end{array}$ & $\begin{array}{l}\cdot \text { Begins the season for } \\
\text { planting rice. } \\
\cdot \text { Rice seeds should not } \\
\text { be planted before the } \\
\text { ceremony. } \\
\cdot \text { Those who plant rice } \\
\text { before the season are } \\
\text { believed to be bitten by } \\
\text { a tiger. }\end{array}$ & In practice. & - & $\begin{array}{l}\text { Village or } \\
\text { Inter Village }\end{array}$ & Village \\
\hline
\end{tabular}

Source: Interview and observation form field work by the first author.

* All of the four annual ceremonies from No. 1 to No. 4 is said to have initiated by the ancestors after negotiating with the tiger in exchange for the human to live nearby forest where tiger habit.

** The four annual ceremonies were practiced at a village where the priest lived but taboos related to the ceremonies were also applied to the other Somrai villages before the war. 
plain why tiger hunting during the war was not mentioned in the village.

Meanwhile, local ceremonies and other traditions related to tiger beliefs were revived when people settled in Village A in the early 1990s. The four annual ceremonies, which were interrupted during the war when the Somrai lived in refugee camps, were reestablished when the priest of the current generation assumed his father's place (Fig. 3).
However, eight traditions related to tiger beliefs are not fully practiced at all levels of society (Table 5-1 and 5-2). This may be caused by the disappearance of the tigers that once attacked humans due to tiger hunting and trade.

In addition, the krâvanh ceremony and harvest in Village A was not resumed because the people were not able to return to the old village near the krâvanh forest, which was occupied by migrants from other provinces who began to

Table 5-2. Changes in practice and effectiveness of traditions related to tiger beliefs in Village A

\begin{tabular}{|c|c|c|c|c|c|c|}
\hline No. & $\begin{array}{l}\text { Case of } \\
\text { traditions }\end{array}$ & $\begin{array}{c}\text { Content of tradition } \\
\text { (taboos, stories, ceremonies) }\end{array}$ & $\begin{array}{l}\text { Condition of practice } \\
\text { since the } 2000 \mathrm{~s}\end{array}$ & $\begin{array}{l}\text { Explained background } \\
\text { for changes in traditions }\end{array}$ & $\begin{array}{l}\text { Practiced level } \\
\text { in society } \\
\text { before the war }\end{array}$ & $\begin{array}{l}\text { Practiced level } \\
\text { in society } \\
\text { after the war }\end{array}$ \\
\hline 5 & $\begin{array}{l}\text { The ceremony to } \\
\text { begin krâvanh } \\
\text { harvest }\end{array}$ & $\begin{array}{l}\text { - The first anncestors of the Som- } \\
\text { ray that settled nearby the krâvanh } \\
\text { forest sent krâvanh to the king. } \\
\text { - Harvesting krâvanh before the } \\
\text { ceremony is prohibited. Harvesting } \\
\text { krâvanh before the season was de- } \\
\text { scribed as "stealing" and those who } \\
\text { do so were believed to be bitten by } \\
\text { a tigers that punish violators. } \\
\text { - This taboo is applied to all of } \\
\text { the Somrai villages and villagers } \\
\text { are not allowed to begin harvest- } \\
\text { ing until the season is officially } \\
\text { opened at the forest near the } \\
\text { oldest village where the ancestors } \\
\text { first settled. }\end{array}$ & Not in practie. & $\begin{array}{l}\text { Interrupted since the } \\
1970 \text { s. Current village } \\
\text { was established away } \\
\text { from the old village } \\
\text { near the krâvanh for- } \\
\text { est. The old village was } \\
\text { occupied by migrants } \\
\text { from other provinces } \\
\text { during the war. }\end{array}$ & Inter Village & - \\
\hline 6 & $\begin{array}{l}\text { Taboo on cap- } \\
\text { turing and hunt- } \\
\text { ing tigers }\end{array}$ & $\begin{array}{l}\text { - The priest and people from the } \\
\text { same family line of the priest } \\
\text { should not manufacture a cage for } \\
\text { capturing and hunting tigers. } \\
\text { - Initiation of the annual ceremony } \\
\text { held four times per year, after } \\
\text { negotiation between the ancestors } \\
\text { and the tiger is said to be related } \\
\text { with this taboo. } \\
\text { - Those who do not belong to the } \\
\text { priest's family can capture and } \\
\text { hunt tigers. }\end{array}$ & $\begin{array}{l}\text { Tigers physically } \\
\text { disappeared around } \\
\text { the village after the } \\
\text { growth of wildlife } \\
\text { trade in the 1990s. }\end{array}$ & $\begin{array}{l}\text { Not explicitly men- } \\
\text { tioned whether the } \\
\text { practice of taboo has } \\
\text { changed. }\end{array}$ & $\begin{array}{l}\text { Individual, } \\
\text { Family }\end{array}$ & $\begin{array}{l}\text { Individual, } \\
\text { Family }\end{array}$ \\
\hline 7 & $\begin{array}{l}\text { Annual cere- } \\
\text { mony for spirits } \\
\text { of family line } \\
\text { (February) }\end{array}$ & $\begin{array}{l}\text { - The ceremony is practiced from } \\
\text { the second day onwards after the } \\
\text { first day of the annual saen meakh } \\
\text { ceremony held at the priest's house. } \\
\text { - This ceremony is practiced by } \\
\text { the villagers from the same family } \\
\text { line. Spirits belonging to individ- } \\
\text { uals who have inherited the spirits } \\
\text { from their ancestors are summoned } \\
\text { during this ceremony. } \\
\text { - One of the spirits among these is } \\
\text { a spirit tiger that takes care of the } \\
\text { planted krâvanh. }\end{array}$ & $\begin{array}{l}\text { Partly practiced. } \\
\text { Some quit practicing } \\
\text { the ceremony. Those } \\
\text { who have spirit ti- } \\
\text { gers practice the cer- } \\
\text { emony every year. }\end{array}$ & $\begin{array}{l}\text { Some villagers who } \\
\text { did not inherited the } \\
\text { spirits to their decen- } \\
\text { dants quit the ceremo- } \\
\text { ny. }\end{array}$ & Family & Family \\
\hline 8 & $\begin{array}{l}\text { Taboo on cap- } \\
\text { turing mountain } \\
\text { crabs }\end{array}$ & $\begin{array}{l}\text { - Individuals who have spirit ti- } \\
\text { gers should not capture mountain } \\
\text { crabs. }\end{array}$ & $\begin{array}{l}\text { In practice. Anyone } \\
\text { who lives in or stay } \\
\text { at the houses where } \\
\text { persons who have } \\
\text { spirit tigers live } \\
\text { should follow this } \\
\text { taboo and should } \\
\text { not bring a mountain } \\
\text { crab into the houses. }\end{array}$ & $\begin{array}{l}\text { Those who have spirit } \\
\text { tigers and their family } \\
\text { members say tigers } \\
\text { still exist nearby al- } \\
\text { though they cannot be } \\
\text { seen. }\end{array}$ & $\begin{array}{l}\text { Individual, } \\
\text { Family }\end{array}$ & $\begin{array}{l}\text { Individual, } \\
\text { Family }\end{array}$ \\
\hline
\end{tabular}

Source: Interview and observation form field work by the first author. 
settle there after 1989, when the Vietnam military withdrew from the area. In addition, some of the forest overlapped with areas where mines had been planted. Krâvanh plants can be found in the forest near the current village, but their growth is sparse and the krâvanh is not sold ${ }^{15}$. Only one case of harvesting krâvanh flowers ${ }^{16}$ has been confirmed: in the 2000s, a group of individuals ( 3 to 5 people) harvested the flowers from the old forest and sold them. The flowers were harvested by members of the younger generation (born in the 1980s) without holding a ceremony, though this seems to be an exceptional case. The elders generally say they are unwilling to harvest krâvanh unless a ceremony for opening the season is held. It is also said that some elders are unwilling to talk about the ceremony because they have been unable to hold it for decades and are concerned that the tradition will not be adhered to even if it is revived.

Table 6. Changes in practice and effectiveness of traditions related to tiger beliefs in Village B

\begin{tabular}{|c|c|c|c|c|c|c|}
\hline No. & $\begin{array}{l}\text { Case of } \\
\text { traditions }\end{array}$ & $\begin{array}{l}\text { Content of traditions } \\
\text { (taboos, stories, } \\
\text { ceremonies) }\end{array}$ & $\begin{array}{l}\text { Condition of practice } \\
\text { since the } 2000 \mathrm{~s}\end{array}$ & $\begin{array}{l}\text { Explained background for } \\
\text { changes in traditions }\end{array}$ & $\begin{array}{l}\text { Practiced level } \\
\text { in society } \\
\text { before the war }\end{array}$ & $\begin{array}{l}\text { Practiced level } \\
\text { in society } \\
\text { after the war }\end{array}$ \\
\hline 1 & $\begin{array}{l}\text { Ceremony to } \\
\text { begin krâvanh } \\
\text { harvest* }\end{array}$ & $\begin{array}{l}\text { - Harvesting krâvanh before } \\
\text { the ceremony is prohibited. } \\
\text { Harvesting krâvanh before } \\
\text { the season was described } \\
\text { as "stealing" and those who } \\
\text { do so were believed to be } \\
\text { bitten by a tiger that punish } \\
\text { violators. }\end{array}$ & $\begin{array}{l}\text { In Practice but not al- } \\
\text { ways followed. } \\
\text { Some villagers and } \\
\text { outsiders pick krâvanh } \\
\text { fruits before the season } \\
\text { is opened.The ceremony } \\
\text { was not held in } 2012 \text {. }\end{array}$ & $\begin{array}{l}\text { - Outsiders are said to } \\
\text { pick krâvanh fruit before } \\
\text { the season is opened. } \\
\text { - Crop damage by an- } \\
\text { imals is interpreted by } \\
\text { villagers as a punishment } \\
\text { against violating the cer- } \\
\text { emony. } \\
\text { - Villagers explained that } \\
\text { interruption of the cere- } \\
\text { mony in } 2012 \text { is relatd to } \\
\text { the ineffectiveness of the } \\
\text { ceremony. }\end{array}$ & Inter Village & Village \\
\hline 2 & $\begin{array}{l}\text { Taboo on clear- } \\
\text { ing the krâvanh } \\
\text { forest }\end{array}$ & $\begin{array}{l}\text { Those who clear the } \\
\text { krâvanh forest was believed } \\
\text { to be bitten by a tiger. } \\
\text { - TS prohibited people to } \\
\text { cut the forest during the } \\
\text { war. }\end{array}$ & $\begin{array}{l}\text { Not in practice. } \\
\text { The forest was cleared. }\end{array}$ & $\begin{array}{l}\text { The forest was cleared } \\
\text { for logging road in the } \\
\text { 1990s. Villagers learned } \\
\text { from outsiders, who ex- } \\
\text { tracted resources from } \\
\text { the forest without nega- } \\
\text { tive consequences. }\end{array}$ & n.d. & Village \\
\hline 3 & $\begin{array}{l}\text { Selecting the } \\
\text { leader for resin } \\
\text { and agar wood } \\
\text { harvest }\end{array}$ & $\begin{array}{l}\text { - A leader was selected to } \\
\text { protect the harvesters from } \\
\text { tiger. }\end{array}$ & $\begin{array}{l}\text { Not in practice. Resin } \\
\text { is harvested without } \\
\text { giving offerings to the } \\
\text { sipirits. Agar wood is } \\
\text { not harvested anymore. }\end{array}$ & $\begin{array}{l}\text { The role of the leader is } \\
\text { not practiced because } \\
\text { tigers are not seen today. }\end{array}$ & $\begin{array}{l}\text { group of indi- } \\
\text { viduals } \\
\text { ( } 5 \text { to } 10 \text { peo- } \\
\text { ple) }\end{array}$ & - \\
\hline 4 & $\begin{array}{l}\text { Taboo on cross- } \\
\text { ing a specific } \\
\text { stream }\end{array}$ & $\begin{array}{l}\text { - People did not dare to } \\
\text { cross this stream because } \\
\text { they were afraid of being } \\
\text { bitten by a tiger. }\end{array}$ & $\begin{array}{l}\text { Not in practice. Cars } \\
\text { and motorbikes cross } \\
\text { the stream. }\end{array}$ & $\begin{array}{l}\text { A logging road which } \\
\text { is now the main road to } \\
\text { district town was con- } \\
\text { structed in the } 1990 \text { s. }\end{array}$ & n.d. & n.d. \\
\hline 5 & $\begin{array}{l}\text { Taboo on using } \\
\text { fishing net in a } \\
\text { specific river }\end{array}$ & $\begin{array}{l}\text { - If fishing net is used in } \\
\text { this river, a tiger was said } \\
\text { to appear in the village. }\end{array}$ & $\begin{array}{l}\text { Not in practice. } \\
\text { Fishing net is used. }\end{array}$ & $\begin{array}{l}\text { Nothing happens } \\
\text { Belief is fading }\end{array}$ & n.d. & n.d. \\
\hline
\end{tabular}

Normally practiced once in three years. The period of the ceremony lasts for three days and three nights. The Ceremony for ceremony is now practiced

6 guardian spirit at the shrine of TS. A white of the village string is set around the $\begin{array}{lll}\text { In Practice. } & \text { Village** } & \text { Village }\end{array}$ shrine to protect people from misfortune and predatory animals including tigers and elephants.

Source: Interview and observation during field work by the first author.

* Besides the krâvanh ceremony restarted by TS in the $1990 \mathrm{~s}$, people who reside in marshland located at east side of Village B also have restarted krâvanh ceremony in the 2000s. The settlement in the marshland is geographically separated from the main village which was established in the early $1990 \mathrm{~s}$.

** Detail information for the ceremony for guardian spirit of the village (No.6) before the war is unconfirmed but it is said that the presit who is responsible for this ceremony resided in other villages of the Chong. 
These findings show a reduction in the use of krâvanh as a source of cash income.

The situation is worse in Village B, where tiger hunting and trade was explicitly reported by villagers (Boonratana 1999), and 6 traditions related to tiger beliefs were not fully practiced at all levels of society (Table 6). The apparent ineffectiveness of tradition was also associated with tiger hunting and resource exploitation. B7, who was engaged in conservation activities, remarked that the reasons for the current resource scarcity included the rapid development of technology, changes in the methods used for resource extraction, and migrants unfamiliar with local traditions. He also explained, "Before, one who violates the traditional law (chbap propeiney) was bitten by a tiger but there are no tigers that bite people today." When asked when tigers were last seen, he replied, "Since around the year 2000, because hunters shot them to get their skins. Tradition is not effective now, only about three percent (of tra-

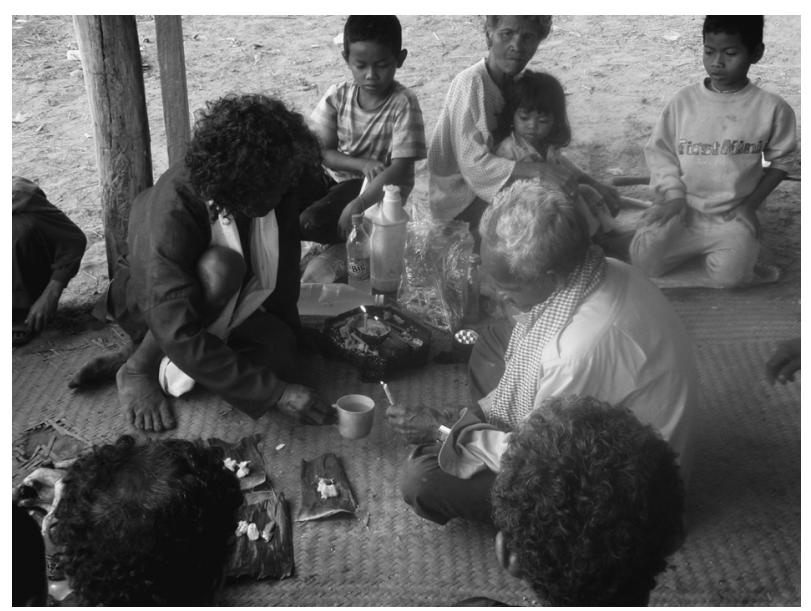

Fig. 3. Annual ceremony saen meakh in February 2011.

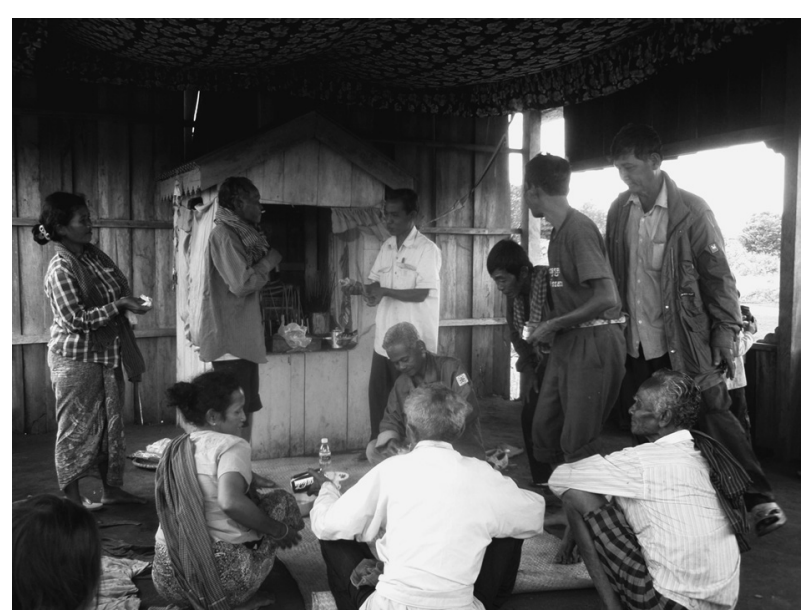

Fig. 4. Krâvanh ceremony in July 2010. dition is effective) if any." This remark shows that the extraction of resources was externally driven by those who did not share local traditions, which resulted in resource scarcity and intensified tiger hunting. It also shows how the relationship between humans and tigers has changed: awe of the tiger has faded as the tiger has become commercialized.

In Village B, the ceremony to begin the krâvanh harvest was revived by TS in the early 1990s after the Chong had settled in the current village (Fig. 4). However, it was held only at the village level and was not held with other villages as it was in the past. The threat of tiger attacks on violators of the ceremony has also become ineffective. For example, people now say "nothing happens" even if krâvanh fruits are picked before the ceremony. Even B8, who succeeded TS and inherited the responsibility of conducting the ceremony, said that the krâvanh forest used to be inhabited by tigers and elephants and that those who violated taboos were attacked by tigers. However, he says that "it is quiet now", suggesting the scarcity of tigers. Villagers also learned from outsiders, who extracted resources from the forest without negative consequences, as described by B2, B9, B10 and others. According to these informants, the krâvanh forest used to be called the forbidden forest (prei tâm). In the past, people did not dare clear this forest because doing so meant being bitten by a tiger or punished by spirits. However, the forest reportedly began to be cleared in the first half of the 1990s, when migrants from other provinces settled the area. These activities overlapped with a period when logging of the krâvanh forest was undertaken for road construction. Forest clearing intensified when hydroelectric dam construction and cultivation for agricultural cash crop planting became widespread in the late $2000 \mathrm{~s}$. B9 mentioned that, before the war, those who cleared krâvanh forest were mauled by tigers; today, no negative consequences are observed. This suggests that the pattern of forest clearance without punishment by tigers may have led people to believe that the taboo is now ineffective.

\section{Crop damage by wildlife as a new punishment}

Though tigers are not seen today, crop damage by other animals has become a problem in the mountains. A 2004 survey of 290 households in 43 villages, including Village A and Village B, reports that among the animals that regularly damaged crops, the wild pig was the most common source of destruction at $95 \%$, followed by porcupines (90\%), monkeys (51\%), rats (38\%), squirrels (33\%), sambars (31\%) and birds (3\%) (Fox 2007).

In Village A, 29 out of 32 households reported crop 
damage by wildlife, including wild pigs (23), monkeys (11), and sambars (2), in 2011. A1 and A2 explained, "Before, there were many tigers and few wild pigs. If tigers decrease, wild pigs will increase" ${ }^{17}$. A2 also said, "Wild pigs did not eat crops before. Crops are damaged because tradition is not followed". A2 refers to instances when agricultural land was cultivated before the season was opened by the annual ceremony held in December or January. People generally explain that land is cultivated before the ceremony by those who want to plant cash crops, such as corn and other crops. The need to plant agricultural cash crops is now increasing because it is becoming difficult to secure a supply of food by harvesting rice due to crop damage by wildlife (Ishibashi 2014). However, cash crops planted in the fields can also be eaten by animals. Some villagers even hold a private ceremony in which they offer chicken and wine and ask the spirits to protect their corn fields from crop damage, which suggests a change in the practice of contacting spirits to receive protection from tiger attacks. The object of fear is also changing. A8 said that he has become afraid of robbers. Others also worried that their harvested crops might be stolen by outsiders if they were kept in the field, as was the practice in the past.

In Village B, crop damage by water buffalos became a serious problem, and in 2011, 11 out of 13 household suffered damage. These water buffalos were brought to the region in 2009 by loggers clearing the area for a hydroelectric dam reservoir. In addition, crop damage by wild pigs, porcupines and caterpillars was reported by 1 or 2 households each. As in village A, this crop damage is perceived by villagers as a punishment for violating tradition. For example, B11 said that "Crop damage occurs if one takes crops without asking, but crops were not eaten by animals until recently". Similarly, krâvanh fruit is also eaten by mice, squirrels, monkeys and wild pigs and is stolen by outsiders. $\mathrm{B} 12$, who is responsible for preparing the krâvanh ceremony, said, "Krâvanh fruits are few because tradition is violated too much! It is like destroying the forest”. B13 said that, under these circumstances, "I'm more afraid of humans than tigers because laborers from outside stole my chickens."

Because of contemporary changes in the two villages, crop damage by wild pigs and other animals is interpreted as punishment for violating tradition, and the villagers' sense of fear is directed to outsiders rather than to tigers.

\section{Current practices associated with tiger beliefs}

Although tiger beliefs are fading at the village level, some say that tigers still exist nearby, although they cannot be seen. This seems to be reflected in the fact that tiger beliefs are still practiced on a smaller scale by families and individuals. This is confirmed by the presence of beliefs associated with spirit tigers in Village A. For example, A2, who inherited a spirit tiger that guards a krâvanh planted by his grandfather, asserted that there was still a tiger that lived in a mountain near the village, but spirits prevented it from being seen.

Villagers continue to hold the family-level ceremony in which they communicate with the spirit tiger summoned during the ceremony. When the spirit tiger possesses a medium (A7), it attracts attention by making gestures that imitate the clearing of undergrowth for krâvanh and amuses the crowd by interacting with the ceremony participants. A7 recalled that she used to enjoy the ceremony when her mother was a medium.

Taboos related to the spirit tiger are also maintained on a small scale. For example, the spirit tiger summoned during the family level ceremony makes a gesture as if to catch a mountain crab with its claw. This gesture is related with a taboo applied specifically to those who have the spirit tiger: they should not capture and bring mountain crabs into their houses. This taboo also applies to anyone who stays in their home, including family members and visitors, thereby extending observance of the taboo to others. A7 said, "The tiger does not bite if a mountain crab is brought into the house, but it comes nearby and walks around the house." A7 added that she can tell when the door creaks that a tiger is nearby. On another occasion, her husband, A9, said, "This place used to be a forest where tigers and elephants appear but they have run away elsewhere during the war. There are no elephants anymore. Tigers still exist but they cannot be seen".

This type of spirit tiger is not found in Village B. Therefore, a similar belief in tigers associated with spirits could not be confirmed.

\section{DISCUSSION}

\section{Effectiveness of punishment by tigers associated with spirits before the war}

A study that discussed the role of supernatural belief in natural resource management (Sasaoka 2012) classifies the meanings and purposes of norms for "indigenous resource management” into socio-economic meanings (e.g., to increase the efficiency of resource use, prevent the depletion of resources or avoid conflict over resources) and religious meanings (e.g., to perform a ritual to appease supernatural 
beings). It also categorizes the mechanisms that enforce people to follow the norms into supernatural agencies that monitor and sanction violators and human punishment and blame.

In the Cardamom Mountains of Cambodia, specifically among the Somrai of Village A and the Chong of Village $\mathrm{B}$, the belief that tigers punished violators seems to have been partially effective before the war. This is apparent in the ceremony that opened the season for the krâvanh harvest, which was held for socioeconomic reasons to prevent "stealing" of krâvanh before the season began ${ }^{18}$.

The discourse that tigers associated with spirits would bite those who violated taboos may have reflected actual fears of physical tiger attacks on humans, but it is probable that this was also emphasized to protect the forest products used for trade from "theft", a metaphor used in the forested areas (e.g., Boomgaard 2002), as the ceremony celebrating the beginning of the krâvanh harvest suggests. It also implies that awe of tigers may have contributed to keeping people from hunting them, even if tiger populations decreased in other areas of Cambodia due to trophy hunting during the colonial period (Guérin 2010). The potentially large tiger populations and the reportedly high density of tigers in the region in the last decade of the 20th century (Weiler et al. 1999; Nowell et al. 1999) may be a result of supernatural beliefs that mitigated hunting pressure on tigers.

\section{Changes in tiger beliefs due to the wildlife trade boom during the war}

The tiger beliefs of the Somrai and Chong have, however, changed due to historic events, namely, the prohibition of religious practices by the state in the 1970s and the rapid growth of the wildlife trade during the war. The interruption of local ceremonies due to political insecurity in the 1970 s impacted the relationship between humans and tigers. The wildlife trade that boomed at the end of the war also significantly affected the relationship between humans and tigers, which went from "people being killed by tigers" to "tigers being killed by people" (Boomgaard 2002). As tigers that physically attack humans have become almost extinct because of the wildlife trade, the relationship between humans and tigers has fragmented, limiting humans' relationship with tigers to the spiritual aspects seen in practice of holding ceremonies.

\section{Variations between the two villages}

The impact of the wildlife trade and warfare on the relationship between humans and tigers differed between the Somrai society in Village A and the Chong society in Village $\mathrm{B}$. The impact depends on the meaning attached to tigers in the two villages and on the location of their new settlements after they were forced out of their original villages during the war and resulting political unrest.

\section{Variations due to differences in the meanings attached to tigers}

An important factor that differentiated the impact of external pressures, especially those of the wildlife hunting and trades, on beliefs in the tiger as a punishing agent is the broader meaning attached to tigers by the inhabitants of the two villages.

In Village A, tiger beliefs are generally associated with variations of the ancestor story and with the ceremonies and taboos. These indicate that tigers are not only considered punishing agents. Spirit tigers help humans access forest products and even amuse people when summoned during a ceremony. In addition, a taboo that prohibited some community members from killing tigers was also confirmed. However, in Village B, tiger beliefs are primarily associated with tigers that punish or attack people. These differences between the two villages have led people in Village A, but not in Village B, to feel not only fear but also a close mental relationship with the tiger.

The above argument is also strengthened when analyzing whether people mention tiger hunting during the wildlife trade boom. In Village A, people did not explicitly discuss such activities, which seems to reflect their close mental relationship with the tiger, as described above. In Village B, however, the ineffectiveness of tiger-related punishments after the height of the wildlife trade was explicitly explained by the disappearance of tigers that physically attack humans. In another words, awe of tigers that punish violators of taboos faded with the rise of wildlife trade that turned tigers into commercial products. However, it should be noted that this change was externally influenced by political and economic factors. The impact of war on wildlife in other areas of Cambodia was driven by the proliferation of modern weapons and external market demands (Loucks et al. 2009). A similar impact has also been observed in the mountains (Boonratana 1999), but here the war had also impacted the relationship between humans and tigers, resulting in the ineffectiveness of the belief that tigers were 
punishing agents

\section{Variations due to the location of the new villages}

Differences between the two villages were also seen in the revival of ceremonies marking the beginning of the krâvanh harvest. These differences reflect the villagers' migration experiences due to the war and their mental relationship with the tiger. Despite their close mental relationship with the tiger, the residents of Village A did not revive the ceremony, unlike those who lived in Village B. This difference was a result of the current location of the two villages. While Village B was established near the krâvanh forest where people used to harvest krâvanh, Village A was established away from the krâvanh forest where the first ancestors of the Somrai are said to have settled when the village was relocated during the war and period of political unrest.

Although restricted access to the krâvanh forest constrained the inhabitants of Village A from reviving the ceremony that begins the krâvanh harvest, other ceremonies, such as the ceremony held four times per year, were reinstituted. This was seen as a way to reestablish the peoples' mental relationship with tigers and with the ancestors of the Somrai. In another words, to admit that the tiger associated with the spirits no longer exists is to deny the basis of the ceremony, especially considering the disappearance of physical tigers after the boom of the wildlife trade. However, in Village B, the disappearance of tigers that punish humans was explicitly confirmed even though the krâvanh ceremony was revived.

\section{Outcome of the disappearance of tigers after the war at different societal levels}

In addition to variations between the two villages, the reaction to the changes precipitated by the war and the wildlife trade also differed by societal level.

\section{Village level: Interpreting crop damage as a new pun- ishment}

The disappearance of tigers that physically attack humans after the war generally diminished the effectiveness of beliefs that viewed tigers as punishing agents. This belief, which used to be practiced at the inter-village level, was scaled down to the village level after the two villages were relocated during the period of political unrest.

Consequently, awareness of the spiritual aspect of tigers became limited in ancestor stories and ceremonies. The threat of tiger attacks on humans is no longer a source of fear. Rather, people now fear crop damage by animals such as wild pigs and thefts perpetrated by outsiders, which lead to the loss of villagers' food supply and income source. Fear of the tiger has transformed into fear of outsiders as the local society has been brought into contact with the outside world since the war. Requests to spirits have also changed. In the past, requests for protection from tiger attacks were made; now, villagers ask the spirits to protect crops from being eaten by animals, which is considered the new punishment. These changes show the interrelation between changes in the ecological system, in the social order and in local interpretations of crop destruction by wildlife (cf. Ueda 1999; 2002). This contemporary change in the relationship between locals and tigers since the tiger has become almost extinct was not thoroughly discussed in previous studies on Southeast Asia (Boomgaard 2002; Guérin 2010; Wessing 1986). This study provides such a discussion.

\section{Family and individual level: Basis for existence of spir- it tiger}

The physical disappearance of tigers that attack humans has caused the belief that tigers are punishing agents to fade, resulting in the ineffectiveness of forest use traditions practiced at the village level. Nevertheless, those who practice tiger beliefs at family and individual levels argue that tigers still exist nearby but do not allow themselves to be seen. Therefore, in a local context, the existence of tigers associated with spirits cannot be explained solely by the population changes of actual tigers.

The closer mental relationship between people and tigers in Village A than in Village B reflected in spirit tiger practices at individual and family levels may explain this finding $^{19}$. Spirit tigers are believed to emerge when krâvanh is planted by individuals. These spirit tigers care for the planted krâvanh so that these individuals and their families can make a living. The spirit tigers belonging to individuals are believed to be inherited by descendants and thereby continue to exist. The ceremonies and taboos related to spirit tigers and their associated practices were typically extended to others, thereby allowing others to internalize their existence today. This set of beliefs, practiced at family and individual levels and transferred between and within generations, may have contributed to the mutual relationship be- 
tween humans and tigers that caused the two to exist as a whole.

This point is relevant to the ontological study of anthropology that questions Western-based descriptions of Animism "as the imputation of life to inert objects" and presents an alternative view that describes life as "immanent in the very process of that world's continual generation or coming-into-being" (Ingold 2006). This suggests that the tigers that physically attack humans and the tigers associated with spirits cannot be divided, nor they can be separated from humans; the basis of their existence is prior to their differentiation (Ingold 2006). The disappearance of tigers that physically attack humans may have fragmented the relationship between humans and tigers, but it did not bring about a complete denial of their relationship. In another words, the physical disappearance of tigers did not necessarily cause the immediate denial of their spiritual existence in the local context.

\section{CONCLUSION}

This study examined how traditional uses of the forest that associate belief in spirits with tigers in the mountains of Cambodia have changed over time, focusing on the impact of the war and the rapid growth of wildlife hunting and trade. The findings of this study show that war and the wildlife trade significantly impacted the tiger beliefs associated with traditional uses of the forest practiced at various societal levels. Indeed, the impact of these factors differed by societal level, suggesting that the extinction of tigers that physically attack humans does not necessarily result in the disappearance of such beliefs at all levels of society. The belief that tigers are punishment agents, which used to be practiced at village or inter-village levels, generally became ineffective. At family and individual levels, however, people still form mental connections with tigers beyond their role as punishing agents and believe in the existence of tigers associated with spirits.

Tigers are now nearly extinct in Cambodia, and future national policies now focus on the restoration of the species (FA 2011). In such case, not only the species itself but also the relationship between humans and tigers in local contexts deserves more attention.

This study shows that it cannot be concluded either to take for granted that locals "in general" are supportive of conserving tiger or to assume locals "in general" are potential threats to tiger. There is even intra-village difference in sense of awe toward tigers and relationship between humans and tigers. Such diversity should be taken into ac- count if the policy for restoration of tiger population considers possibilities and constrains for implementing it through cooperation and understanding from locals. This study also indicates that, in the past, the relationship between humans and tigers was formed through the use of the forest. However, historical process in the researched site showed peoples' access to the forests has been constrained by national policies during the political unrest. Even now, in the post-war period, legal recognition of rights to de facto use of the forest by locals is limited (Baird 2013). Hence, tiger restoration may take place in the uneven power landscape unless due consideration is given to correct power inequality among different levels of society, especially among the locals and the government.

It should also be noted that beliefs are not necessarily shared by all people and at all levels of a society and can change and differ according to context. Further investigation of the influence of contemporary changes on social relations associated with the traditional use of forest and peoples' adaptation to such changes at different levels of society is needed. Such information is crucial to assessing problems in environmental management from multiple levels of society while considering the impact of contemporary changes (e.g., Cash et al. 2006).

ACKNOWLEDGMENTS We are grateful to the villagers and other persons and organizations who provided support for this study. This research was funded by The Konosuke Matsushita Memorial Foundation scholarship program from April 2010 to March 2012 and by the JSPS KAKENHI Grant in Aid for JSPS Fellows Number 24 • 7175. Fieldwork was made possible through support from the Forestry Administration and the Ministry of Environment of Cambodia, the Royal University of Phnom Penh, Fauna \& Flora International and Conservation International. The views and opinions expressed in the article are not necessarily those of the organizations that supported this research. Colleagues from the Laboratory of Global Forest Environmental Studies at the University of Tokyo and two anonymous reviewers provided helpful comments to improve earlier versions of this article.

\section{NOTES}

\footnotetext{
${ }^{1}$ The names of the villages and the interviewees are anonymized to protect participants' privacy.

${ }^{2}$ Por or Pear is the term used by the dominant Khmer, whereas the Por refer to themselves as Somrai in Battambang province.
} 
${ }^{3}$ A household is locally considered to belong to the ethnic minority in the researched villages if either of the spouses is Chong or Somrai, even if the other spouse is Khmer.

${ }^{4}$ Number of the households and population includes Village B and neighboring village.

${ }^{5}$ The previous name of what is now known as Thailand. A series of conflicts among local forces in Cambodia occurred between the $17^{\text {th }}$ and $19^{\text {th }}$ centuries. These conflicts involved war with Siam and Vietnam (Amakawa 2001).

6 "Inter-village" is relationship between two or more villages situated in different geographical location but come together for shared purpose such as holding ceremonies.

${ }^{7}$ Although this report is unconfirmed, a male cousin of A7 also seems to have a spirit tiger: the spirit was summoned during a ceremony held by the man's family.

${ }^{8}$ Those with spirit tigers seem to be limited to the abovementioned individuals in Village A. Krâvanh was also planted and harvested in other forests near the Somrai villages, but those who participated in these activities did not necessarily have a spirit tiger.

${ }^{9}$ This ceremony is held at the same period as the annual saen meakh ceremony, which lasts for two weeks and is held in February. Village-level ceremonies are held at the priest's house on the first day and last day, and familylevel ceremonies are held the remaining days. Familylevel ceremonies are held each night by people from the same family line, but they can also be held jointly with those from different family lines.

${ }^{10}$ The Somre belong to the Pearic language group. Elders say that it was the Somre who first inhabited the area near Village B and offered krâvanh to the king, claiming that the Chong came to live in the area more recently.

${ }^{11}$ It is said that krâvanh was harvested near Village A and sold to Thailand to increase the government's revenue during the communist regime, though these details are unconfirmed.

${ }^{12}$ Detainees were forced to cultivate rice to increase the rice yield to meet national quotas, but surplus rice was taken away for export. Many died during this time from disease, imposed overwork and malnutrition (Chandler 2008: 262-264).

${ }^{13}$ A1 said he found agar wood in this mountain. This mountain is not a krâvanh harvest site but is worshipped as a place where spirits dwell and has been used to harvest other forest products.

${ }^{14}$ 1. Cardamom Mountains, 2. Phnom Oral, 3. Elephant Mountains, 4. Kampong Thom, 5. South of Sre Pok, 6. Northeast Buffer, 7. Vicachey, 8. Northern Plains, 9. Pailin. The locations of the regions in Cambodia include southwest and west $(1,2,3,9)$, central $(4)$, northeast $(5,6$,
7), and north (8).

${ }^{15}$ Some villagers had planted krâvanh near their homes. This krâvanh was brought from the forest near the current village. These villagers did not have the spirit tiger described earlier.

${ }^{16}$ Harvesting flowers is unusual; it is the fruit that was traditionally harvested.

${ }^{17}$ Studies from other Asian countries report that tigers prefer to prey on wild pigs that damage crops, which is appreciated by humans (Boomgaard 2002: 23-24, 59; Ueda 1999: 42; 2002: 118-119).

${ }^{18}$ Although not within the scope of this paper, enforcement by humans (militia, soldiers and forestry officers and villagers) was also practiced near Village B before the war, though villagers in Village A said there was no such practice. This difference may exist because of the differing extents to which the local societies had been integrated into the state before and during the colonial period. This topic will be discussed further in another paper.

${ }^{19}$ One villager in Village B also asserted the existence of the invisible tiger, but this remark may be related to a broader awe of nature. This principle may also apply to Village A, where spirits in general are said to be invisible. Further investigation is needed to explain this point by focusing more broadly on belief systems in the mountains.

\section{REFERENCES}

Amakawa N. 2001. Kambojia ni okeru kokuminkokkakeisei to kokka no ninaite o meguru funso (State formation and conflict over state power in Cambodia). In: Amakawa N (ed) Kambojia no fukko kaihatsu (Reconstruction and Development in Cambodia). Ajia keizaikenkyujo (Institute of Developing Economies), Chiba. 21-65.(in Japanese).

Ang C. 1986. Les êtres surnaturels dans la religion poplulaire khmère, Cedoreck: Paris.

Anonymous. 1968. Enquete ethnographique au village de Ta-Tok, en Battambang (1ére partie). Bulletin des etudiants de la faculte d'archeologie. Université Royale des Beaux-Arts, Phnom Penh. 4-24.

Baird IG. 2013. 'Indigenous Peoples' and land: Comparing communal land titling and its implications in Cambodia and Laos. Asia Pacific Viewpoint. 54(3): 269-281 http://dx.doi. org/10.1111/apv.12034

Baradat R. 1941. Les Sâmré ou Peâr, population primitive de 1' ouest du Cambodge. Bulletin de École Française d'ExtrêmeOrient 41: 1-150.

Boomgard P. 2001. Froniers of fear: Tigers and people in the Malay world 1900-1950. Yale University Press, New Haven and London. 
Boonratana R. 1999. A preliminary wildlife survey in the Cardamom mountains region of southwestern Cambodia. In: Momberg F and Hunter W (eds) Conservation status of the Cardamom mountains in southwestern Cambodia: Preliminary studies. Fauna \& Flora International - Indochina Programme, Hanoi. 11-27.

Bourdier F. 2009. Introduction. In: Bourdier F (ed) Development and dominion: Indigenous peoples of Cambodia, Vietnam and Laos, White Lotus, Bangkok. xix-xxix.

Cash DW, Adger WN, Berkes F, Garden P, Lebel L, Olsson P, Young O. 2006. Scale and cross-scale dynamics: Governance and information in a multilevel world. Ecology and Society 11 (2), 8. http://www.ecologyandsociety.org/vol11/iss2/art8/ (cited 2014 November 29).

Chandler DP. 2008. A history of Cambodia fourth edition. Westview Press, Boulder, Colorado.

Colding J, Folke C. 2001. Social taboos: "Invisible" systems of local resource management and biological conservation. Ecological Applications 11 (2): 584-600.

Dove MR, Sajise PE, Doolittle AA. 2011. Changing ways of thinking about the relations between society and environment. In: Dove MR, Sajise PE, Doolittle AA (eds) Beyond the sacred forest: Complicating conservation in Southeast Asia. Duke University Press, Durham and London. 1-34.

Ebihara M. 1968. Svay: A Khmer village in Cambodia. Ph.D. thesis. Colombia University.

[FA] Forestry Administration. 2011. Cambodia tiger action plan 2011-2022 provisional interim $1 \mathrm{draft}$, march 2011. In: Secretariat of Global Tiger Forum (ed) Action tiger 2nd edition: Tiger action plans of 13 tiger range Countries. Wildlife Trust of India, Uttar Pradesh. 95-118. http://www.catsg.org/fileadmin/ filesharing/3.Conservation_Center/3.4._Strategies__Action_ Plans/Tiger/tiger\%20action\%20plans.pdf) (cited 2015 October 20).

Fox M. 2007. Socio-economic studies of Phnom Samkos Wildlife Sanctuary, 2004-2006. Cardamom Mountains Wildlife Sanctuaries Project, Ministry of Environment and Fauna \& Flora International, Phnom Penh.

Gadgil M, Vartak VD. 1976. Sacred groves of western Ghats in India. Economic Botany 30(2): 152-160.

Gray TNE, Ou R, Huy K, Pin C, Maxwell AL. 2012. The status of large mammals in eastern Cambodia: A review of camera trapping data 1999-2007. Cambodian Journal of Natural History 2012: 42-55.

Guérin M. 2010. Européens et prédateurs exotiques en Indochine, le cas du tigre. In: Moriceau JM, Madeline P (eds) Repenser le sauvage grâce au retour du loup: Les sciences humaines interpellées. Presses Universitaires de Caen, Caen. 211-224. $\mathrm{http} / /$ hal.archives-ouvertes.fr/docs/00/49/23/59/PDF/GuerinEuropeen-predateurs-exotiques-Indochine.pdf (cited 2014 September 19)

Hamilton LS. 2002. Forest and Tree Conservation through Metaphysical Constraints. The George Wright Forum 19(3): 57-78.

Holden J, Neang T. 2009. Small carnivore records from the Cardamom Mountains, southwestern Cambodia. Small Carnivore Conservation 40: 16-21.
Ingold, T. 2006. Rethinking the animate, re-animating thought. Ethnos 71(1): 9-20.

Ironside J. 2013. Thinking outside the fence: exploring culture/ land relationships: A case study of Ratanakiri province, Cambodia. Ph.D Thesis. University of Otago. http://hdl.handle. net/10523/4364 (cited 2014 December 1).

Isara C. 2002. Dialects of Chong. The Mon-Khmer Studies Journal 32: $55-70$.

Ishibashi H. 2010. Kingendai Kambojia no shakaihendo ka ni okeru karudamon riyo no dotai: Shukakugenba no tosotsusha, hanbaiseido, hozenkatsudo o megru chiikikankyoshi (Social changes and dynamics in use of cardamom in Cambodia: Environmental local history on harvest leader, marketing system and conservation activity in the Cardamom Mountains). Tonan Ajia Kenkyu (Southeast Asian Studies) 48 (2): 155-204. (in Japanese).

Ishibashi H. 2014. Kambojia sanson no kyukoushoku: Yamuimo kara mita shoku no jikyu no rekishi to genzai. (Famine food in mountain village of Cambodia: Historical and contemporary condition of self-supply of food reflected in utilization of Yam). Fukyosha, Tokyo. (In Japanese) .

Kent EF. 2010. A road runs through it: Changing meanings in a sacred grove in Tiruvannamalai, Tamil Nadu. Journal for the Study of Religion, Nature and Culture 4(2): 213-231.

Long B, Roth B, Holden J, Uck S. 2000. Large Mammals. In: Daltry JC and Momberg F (eds) Cardamom Mountains Biodiversity Survey 2000. Fauna \& Flora International, Cambridge 49-68.

Loucks C, Mascia MB, Maxwell A, Keavuth H, Kong D, Nareth C, Long B, Cox N, Teak S. 2009. Wildlife decline in Cambodia, 1953-2005: Exploring the legacy of armed conflict. Conservation Letters 2(2): 82-92. DOI: 10.1111/j.1755-263X.2008. 00044.x

Martin MA. 1997. Les Khmers daeum, "Khmers de l'origine ": Société montagnarde et exploitation de la forêt. De l'écologie à l' histoire. Presses de l'École française d’Extrême-Orient, Paris.

Momberg F, Weiler H (eds) 1999. Conservation status of the Cardamom Mountains in southwestern Cambodia: Preliminary studies. Fauna \& Flora International- Indochina Programme, Hanoi.

Nowell K, Sun H, Hunter W, Smith JLD. 1999. National status survey for tigers in Cambodia. Cat News. June 1999. http:// khmerinsilent.blogspot.jp/2009/06/national-status-survey-fortigers-in.html (cited 2014 April 30).

Sasaoka M, Laumonier Y. 2012. Suitability of local resource management practices based on supernatural enforcement mechanisms in the local social-cultural context. Ecology and Society 17 (4), 6. http://dx.doi.org/10.5751/ES-05124-170406 (cited 2014 April 28).

Sasaoka M. 2012. Shigenhozen no kankyojinruigaku: Indonesia sanson no yaseidoubutsu riyo kanri no minzokushi (Environmental anthropology of resource conservation: Ethnography of wildife use and management of Indonesian mountain village). Commons, Tokyo. (in Japanese).

Sheridan MJ. 2008. The dynamics of African sacred grovesecological, social \& symbolic process. In: Sherdian MJ. and 
Nyamweru C (eds) African sacred groves: Ecological dynam$i c s$ and social change. Ohio University Press, Athens 9-40.

Sun H. 2000. Status of the tiger and its conservation in Cambodia. MSc Thesis. University of Minnesota. http://www. carnivoreconservation.org/files/thesis/hean_2000_msc.pdf (cited February 14, 2014)

Ueda M. 1999. Zokibayashi o meguru tora to hito: 18 seiki no tonan sanchi. Chugoku: Shakai to bunka. 14: 28-45. (Tigers, people, and forests in the mountainous regions of southeast China during the $18^{\text {th }}$ century. China: Society and Culture) (in Japanese).

Ueda M. 2002. Tora ga kataru chugokushi: Ekorojikaru historii no kanosei (Tiger narrates Chinese history: Possibility of ecological history). Yamakawashuppansha, Tokyo (in Japanese).
Vickery M. 1999. Cambodia 1975-1982 second edition. Silkworm Books, Chiang Mai.

Weiler H, Roth B, and Uch S. 1999. Tiger conservation workshops and hunter interviews in Koh Kong and Pursat Provinces. In: Momberg F, Weiler H (eds) Conservation status of the Cardamom Mountains in southwestern Cambodia: Preliminary studies. Fauna \& Flora International - Indochina Programme, Hanoi. 28-40.

Wessing R. 1986. The soul of ambiguity: The tiger in Southeast Asia. Center for Southeast Asian Studies Northern Illinois University, DeKalb.

Received: August 7, 2014

Accepted: June 16, 2015 